\title{
Procalcitonin values in respiratory infections children under five years old viral infections versus bacterial infections
}

\author{
E1 Ftouh $\mathrm{S}^{1 *}$, Seffar $\mathrm{M}^{2}$, Kettani $\mathrm{C}^{2}$, Mahraoui $\mathrm{C}^{2}$ and Tligui $\mathrm{H}^{1}$ \\ ${ }^{1}$ Research laboratory of CHUIS, University Mohamed V of Rabat, Morocco \\ ${ }^{2}$ Hopital d'Enfants de Rabat, Centre Hospitalier Universitaire Ibn Sina, Morocco
}

\begin{abstract}
Background/Aims: Procalcitonin (PCT) may prove to be a useful marker to differentiate viral respiratory infection from bacterial respiratory infection episodes in children.

Methods: Children under 5 years old with suspected respiratory infections and responded to inclusion criteria had biochemical analysis blood specimens (PCT and CRP), bacteriological (Phoenix Automated Microbiology System) and molecular analysis (blood culture and Respifinder Test for nasal aspirations). All data were analysed with parametric and non-parametric test.

Results: Of the 664 included patients, $54(9,6 \%)$ had no-infection and $610(78,4 \%)$ had respiratory infection of whom $571(86 \%)$ were viral infections. The PCT median value reached $0.14 \mathrm{ng} / \mathrm{ml}$ while it attained $0,25 \mathrm{ng} / \mathrm{ml}$ in bacterial infections, which were about 39 cases (5.9\%) only. Thirty-five (35), 4\% of paediatric cases had PCT values under $0,1 \mathrm{ng} / \mathrm{ml}$ serum concentration, and $72,6 \%$ under $0,5 \mathrm{ng} / \mathrm{ml}$. There were no significant differences in terms of PCT median between viral infections, co-infections and no-infection. (0.14 versus 0.00 versus 0.1$) \mathrm{ng} / \mathrm{ml}$ PCT values remain normal in viral infection 0,14 (IQR: $0.06-0.64) \mathrm{ng} / \mathrm{ml}$.
\end{abstract}

Conclusions: PCT was more useful for discrimination between viral and bacterial infection. Thus, PCT could be used in paediatric respiratory infection to decide on the necessity of the use of the antibiotic treatment and its monitoring.

\section{Introduction}

Paediatric respiratory tract infection is a major public health in Morocco. A study conducted reported that the aetiologies of respiratory infection in children less than five years old are mainly viral [1]. Furthermore, bacterial and viral respiratory children infections often present with similar symptoms. Infection misdiagnosis leads to an antibiotic overuse and thus increases resistance emergence [2-5]. Between 80 and $90 \%$ of all antibiotics are prescribed for tract respiratory infections despite the predominately viral origin of the infection [6]. The use of Procalcitonin (PCT) as reliable blood biomarker mirroring the host response to infection, and as a suitable guide differentiating bacterial from viral respiratory infection in children was evaluated in many studies [7]. Procalcitonin (PCT) is the prohormone of calcitonin produced by the thyroid gland in response to inflammation caused by bacterial infection [8]. In healthy individuals PCT is $<0,05 \mathrm{ng} / \mathrm{ml}$, and increases rapidly within 3 hours of the development of bacterial infection [9]. PCT levels peak within $6 \mathrm{~h}$ to $12 \mathrm{~h}$ and remain high until the infection declines either by the antibiotic therapy or by the host immune system [10]. Once the infection is managed the PCT value decreases half daily [11]. Inversely, in response to viral infections PCT levels stay normal, interferon Gama, a cytokine released in response to viral infections blocks the up regulation of PCT resulting in higher specify of PCT to-ward bacterial infections $[12,13]$.

In this study, we aimed to evaluate the PCT usefulness in differentiating paediatric patients with viral from bacterial low respiratory infections.

\section{Methods}

\section{Study setting and procedures for recruited children}

Data was collected from a study, which was conducted from 2010 to 2011 in Morocco's capital at the "Hôpital d'Enfant de Rabat" to define the epidemiology and aetiology of respiratory distress at HER.

Inclusion criteria were children aged from 2-59 years old admitted to HER with respiratory symptomatology. Exclusion criteria were non-respiratory illness, or a condition not caused by respiratory illness, or in the event of evidence of a foreign body in the respiratory tract.

An antero-posterior chest X-ray, nasal and pharyngeal swabs for diagnosis of bacterial infection/carriage, and a nasopharyngeal aspirate (NPA) for diagnosis of respiratory viruses by molecular techniques were collected. Venous blood was also collected for blood culture, and biochemistry tests including Procalcitonin (PCT).

${ }^{\star}$ Correspondence to: El Ftouh S, Research laboratory of CHUIS, University Mohamed V of Rabat, Morocco, E-mail: sobhaelftouh13@gmail.com

Key words: procalcitonin (PCT), respiratory infection, bacteria, virus, children

Received: February 11, 2019; Accepted: February 18, 2019; Published: February 22, 2019 


\section{Laboratory tests}

Blood samples are cultured using an automated blood culture system (BD Bactec, BD, USA). Bacterial isolates are identified by Phoenix Automated Microbiology System (PHX system, BD) or standard procedure [1]. The presence of Streptococcus pneumoniae in blood samples is investigated by real-time PCR. In addition, Respifinder test explored viral infection in NAP samples [1]. Levels of serum PCT are tested using a mini-Vidas apparatus [1].

\section{Statistical analysis}

Statistical analyses are performed with IBM SPSS version 19 (IBM Statistics 19). Demographic data, PCT level, and patient outcomes are compared between the viral infection and bacterial infection groups by Mann-Whitney $U$ test. A probability of $<0,05$ was considered statistically significant. Medians and interquartile ranges (IQRs) are presented for non-normally distributed variables and means with corresponding standard deviations are presented for normally distributed variables.

\section{Ethics}

The protocol and informed consent documents were approved by the Ethics Committee of the Hospital Clinic (Barcelona, Spain) and by the Comité d'Ethique de la Recherche' Biomédicale (Depart No125216 Dec 2009) of the Faculty of Medicine in Rabat.

\section{Results}

Six hundred and sixty-four (664) children responded to the inclusion criteria during the study period, including 248 (31, 9\%) females and $416(53,5 \%)$ males. The median age of the study patients was 19 (IQR 10-33) months old. The population baseline characteristics are shown in table 1 (Figure 2) and PCT serum concentrations test are shown in table 2 .

Table 1. Baseline characteristics

\begin{tabular}{|l|l|}
\hline $\mathbf{N}=\mathbf{6 6 4}$ & $19(10-33)$ \\
\hline (Gender) Age (Months) & $416(53,5 \%)$ \\
\hline M & $248(31,9 \%)$ \\
\hline F & \multicolumn{2}{|l|}{} \\
\hline Type of infection & $54(6,9 \%)$ \\
\hline No infection & $35(5,3 \%)$ \\
\hline Bcterial infection only & $571(86 \%)$ \\
\hline Viral infection & $4(0,6 \%)$ \\
\hline Co-infection & $39(5,9 \%)$ \\
\hline Bacterial infection & $7(17,94 \%)$ \\
\hline Type of Gram & $15(38,46 \%)$ \\
\hline Atypical bacteria & $17(43,58 \%)$ \\
\hline Gram-Negative bacteria & \\
\hline Gram - Positive bacteria & $22(3 \%)$ \\
\hline Infection site & $17(2,2 \%)$ \\
\hline Sepsis & $0.14(0,60-0,65)$ \\
\hline Localized Infection & \\
\hline PCT ng/ml & $235(35,4 \%)$ \\
\hline Thresholds & $122(18,4 \%)$ \\
\hline PCT $<0,1$ ng/ml & $307(46,2 \%)$ \\
\hline $0,1>$ PCT $<0,25$ & $482(72,6 \%)$ \\
\hline$>0,25$ & $72(10,8 \%)$ \\
\hline PCT $<0,5$ ng/ml & $63(9,5 \%)$ \\
\hline $0,5>$ PCT $<2$ & $47(7,1 \%)$ \\
\hline $2>$ PCT $<10$ & \\
\hline$>10$ & \\
\hline
\end{tabular}

Table 2. Procalcitonin Concentration (ng/ml)

\begin{tabular}{|c|c|}
\hline Patient's variables & Median (IQR) \\
\hline Absence of infection & $0,13(0.07-0.35)$ \\
\hline Viral infection & $0,14(0,06-0.64)$ \\
\hline Bacterial infection & $0,25(0.1-4,82)$ \\
\hline Co-Infection & $0(0-76,92)$ \\
\hline A typical bacterium & $0,49(0,49-0,49)$ \\
\hline Gram-Negative bacteria & $0,21(0,82-10,73)$ \\
\hline Gram- Positive bacteria & $0,15(0,17-10,73)$ \\
\hline
\end{tabular}

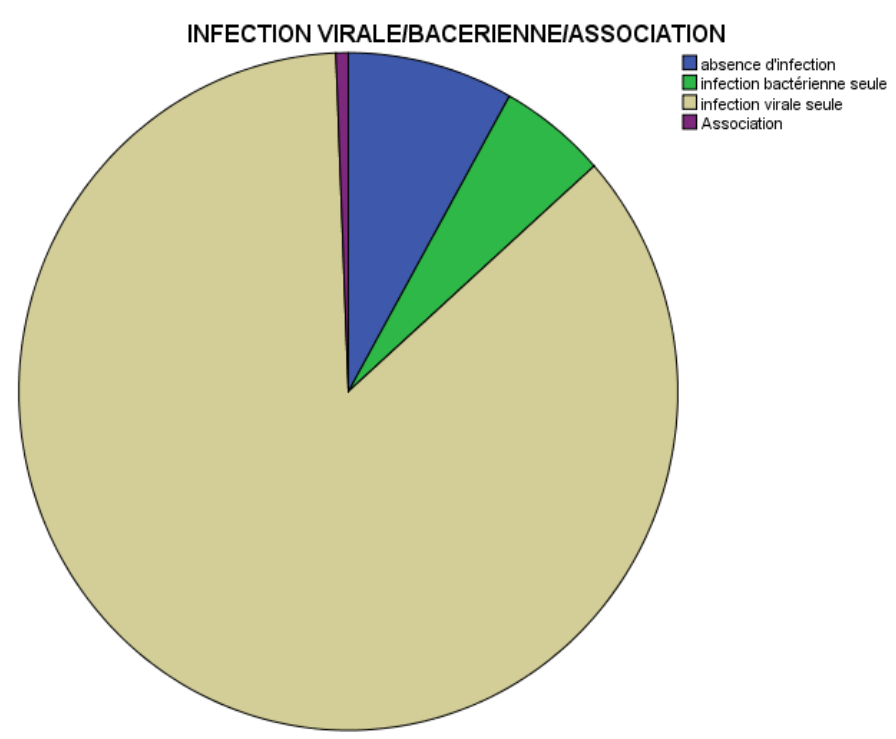

Figure 1. Comparison of infection distribution

The resulting cohort included 664 children, comprised 571 (86\%) viral respiratory infection and $39(6,5 \%)$ bacterial infection which is divided in co-infection (virus and bacteria) $4(0,6 \%)$ and bacterial infection only $39(5,9 \%)$.

In addition, there were 22 (3\%) cases of septicemia. Microorganisms identified in both septicemia and local infections were: Gram negative bacteria $15(38,46 \%)$, Gram Positive bacteria 17 (43, 58\%) and atypical bacteria $7(17,94 \%)$.

The median serum PCT level was 0.14 (IQR: 0,06-0,65) ng/ml. Depending on sepsis probable diagnosis threshold, PCT values were put in four groups, unlikely sepsis $482(72,6 \%)$, moderate risk $72(10$, $8 \%)$, high risk $63(9,5 \%)$, and severe sepsis $47(7,1 \%)$.

In the same way, results found according to respiratory low infection probable diagnosis threshold were: no risk $235(35,4 \%)$, low risk $122(18,4 \%)$ and probable infection $307(46,2 \%)$. The thresholds used in this study are shown in figure 2 and figure 3.

Concerning comparative tests, there were very significant difference in terms of PCT values between viral infection and bacterial infection $p=0,01$. In terms of comparative test of PCT values there were no significant differences $(p=0,27 ; p=0,86)$ between viral infection versus co-infection and viral infection versus absence of infection.

\section{Discussion}

One of the main goals of this experiment was to show how PCT could distinguish between viral respiratory infection and bacterial ones, in a cohort of 664 children under 5 years old, whom were recruited from HER as part of wider research attempting to define epidemiology 


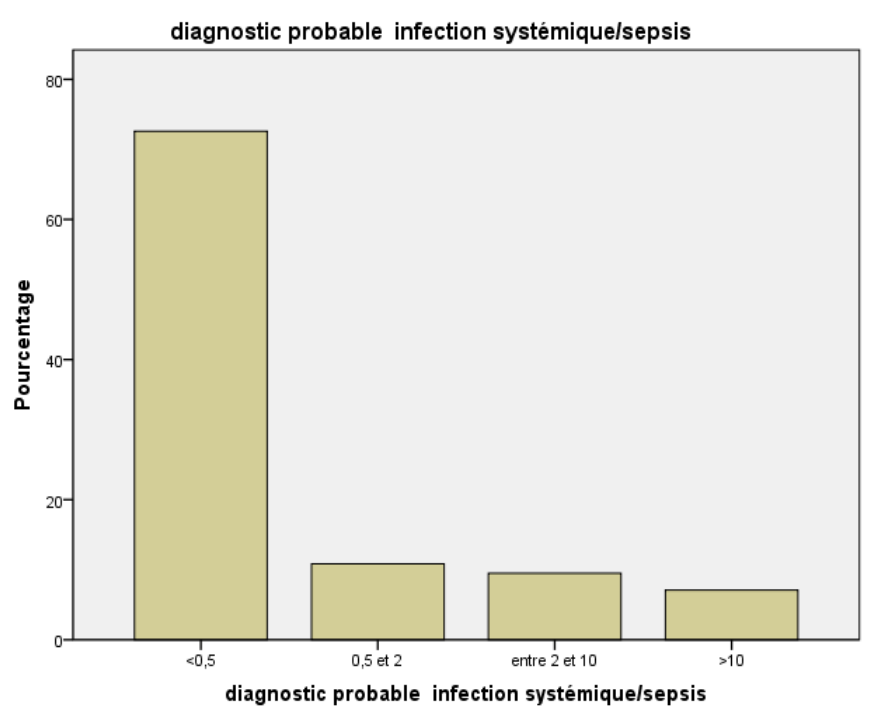

Figure 2. Procalcitonin levels according to probable diagnosis sepsis threshold

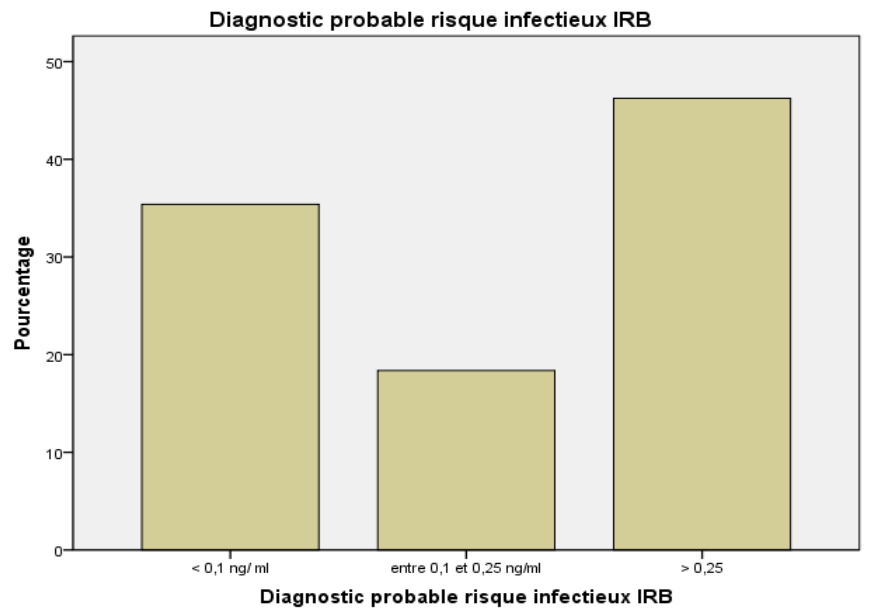

Figure 3. Procalcitonin levels according to probable diagnosis respiratory infection

and aetiology of respiratory distress in Morocco. So, we evaluated the value of PCT as a marker for diagnosis of viral and bacterial lower respiratory tract infection.

\section{Viral infection}

Our results showed that the paediatric respiratory tract infections in 664 children less than five years old are in general viral infections. This reflect the low PCT levels which were mostly under $0,1 \mathrm{ng} / \mathrm{ml}$ serum concentration in $35,4 \%$ cases, and under the $0,5 \mathrm{ng} / \mathrm{ml}$ serum concentration in $72,6 \%$ cases. Several studies have reported that PCT levels remained low $(<0.5 \mathrm{ng} / \mathrm{ml})$ in viral infections [14-16]. Both Patrick Joseph [16] and Toikka [17] have found low PCT levels which are respectively $0,75 \mathrm{ng} / \mathrm{m}$ and $0,56 \mathrm{ng} / \mathrm{ml}$ in viral pneumonia cases. In the other hand Guoji Zhu [18] has found a median of $0.25 \mathrm{ng} / \mathrm{ml}$ in a paediatric group of 50 children, with one case greater than or equal to $2 \mathrm{ng} / \mathrm{ml}$ and three cases which had been between $0,8-1,5 \mathrm{ng} / \mathrm{ml}$.

Our finding concurs with other studies. In fact, our PCT median value reached $0.14 \mathrm{ng} / \mathrm{ml}$ in viral infection versus $0.13 \mathrm{ng} / \mathrm{ml}$ in no infection group. Unlike what was shown by Branch [19], 17\% of viral infection were $>0,25 \mathrm{ng} / \mathrm{ml}$ value, we found that PCT levels were $<0$, $25 \mathrm{ng} / \mathrm{ml}$ in $18,4 \%$ and $>0,25 \mathrm{ng} / \mathrm{ml}$ in $46,2 \%$.

This can be explained by down regulation due to cytokines release in response to viral infections, such as gamma interferon (INF)- $\gamma$. Hence Procalcitonin synthesis is not induced in most viral infections $[13,20-22]$, and thus the majority of PCT values were close to normal. These results showed higher specificity of PCT towards bacterial infection.

\section{Bacterial infection}

In the 39 cases of bacterial infection found, $52.7 \%$ were less than $0.5 \mathrm{ng} / \mathrm{ml}$. According to the Hedlund study [23], PCT appears to rise more often when the bacterium is a pyogenic than when it is an atypical or intracellular organism. Indeed, some infections, especially due to intracellular bacteria, are not accompanied by a rise in PCT. This is consistent with our results: in the 39 bacterial infection founded, 7 cases had a Mycoplasma pneumonia with a PCT value that varies between $0.05 \mathrm{ng} / \mathrm{ml}$ and $0.5 \mathrm{ng} / \mathrm{ml}$.

On the other hand, 7 cases took antibiotics 2 weeks before the PCT assay. Thus, 13 cases showed PCT values ranging from 0.05 to $0.5 \mathrm{ng} / \mathrm{ml}$. This, according to Hausfater [24], may correspond to the circumstances in which sampling takes place, which coincides with either the early phase of the infection, that is to say before the 3 hours following the stimulation of the PCT, or it coincides with an antibiotic therapy phase, as well and given the kinetics of rapid decline of the marker, the PCT normalize.

The remaining 13 cases had a PCT value greater than $10 \mathrm{ng} / \mathrm{ml}$ with a difference between gram-negative $0.21 \mathrm{ng} / \mathrm{ml}$ (IQR: 0.82-10.73) and Gram-positive $0.15 \mathrm{ng} / \mathrm{ml}$ (IQR: 0.17-10.73). This is in line with what was reported by Kocazeybek [ 25].

In conclusion, this study showed that serum PCT levels could be used as a powerful biomarker in paediatrics respiratory infections for discrimination between bacterial and viral aetiologies and could reduce antibiotic prescribing rates in the era of multiples drug resistant bacterial strains.

\section{References}

1. Jroundi I, Mahraoui C, Benmessaoud R, Moraleda C, Munoz Almagro C, et al. (2017) Streptococcus pneumoniae carriage among healthy and sick pediatric patients before the generalized implementation of the 13-valent pneumococcal vaccine in Morocco from 2010 to 2011. J Infect Public Health 10: 165-170. [Crossref]

2. Van den A, Thompson MJ, Haj-Hassan T, Stevens R, Moll H, et al. (2011) Diagnostic value of laboratory tests in identifying serious infections in febrile children: systematic review. $B M J$ 342: d3082. [Crossref]

3. Nijman RG, Moll HA, Smit FJ, GervaixA, Weerkamp F, et al. (2014) C-reactive protein, procalcitonin and the lab-score for detecting serious bacterial infections in febrile children at the emergency department: a prospective observational study. Pediatr Infect Dis J 33: e273-e279. [Crossref]

4. Galetto-Lacour A, Zamora SA, Gervaix A (2003) Bedside procalcitonin and C-reactive protein tests in children with fever without localizing signs of infection seen in a referral center. Pediatrics 112: 1054-1060. [Crossref]

5. Gilsdorf JR (2012) C reactive protein and procalcitonin are helpful in diagnosis of serious bacterial infections in children. J Pediatr 160: 173-174. [Crossref]

6. Wu G, Wu S, Wu H (2017) Comparison of Procalcitonin Guidance Administered Antibiotics with Standard Guidelines on Antibiotics Therapy in Children with Lower Respiratory Tract Infections: A retrospective Study in China. Med Princ Pract 26: 316320. [Crossref]

7. Ashkenazi-Hoffnung L, Oved K, Navon R, Friedman T, Boico O, et al. (2018) A host-protein signature is superior to other biomarkersfor differentiating between bacterial and viral disease in patients with respiratory infection and fever without source: a prospective observational study. Eur J Clin Microbiol Infect Dis 37: 1361-137. [Crossref] 
8. Maruna P, Nedelníkova K, Gurlich R (2000) Physiology and genetics of procalcitonin. Physiol Res 49: S57-61. [Crossref]

9. Gendrel D, Bohuon C (2000) Procalcitonin as a marker of bacterial infection. Pediatr Infect Dis $J$ 19: 679-87. [Crossref]

10. Lebel MH, Gauthier M, Lacroix J, Rousseau E, Buithieu M (1989) Respiratory failure and mechanical ventilation in severe bronchiolitis. Arch Dis Child 64: 1431-1437. [Crossref]

11. Schuetz P, Albrich W, Mueller B (2011) Procalcitonin for diagnosis of infection and guide to antibiotic decisions: past, present and future. BMC Med 22: 107. [Crossref]

12. Schuetz P, Amin DN, Greenwald JL (2012) Role of Procalcitonin in managing adult patients with respiratory tract infections. Chest 141: 1063-1073. [Crossref]

13. El-Azem AA, Hamdy G, Saraya M, Fawzy E, Anwar E, et al. (2013) The role of Procalcitonin as guide for the diagnosis, prognosis, and decision of antibiotic therapy for lower respiratory tract infections. Egypt J Chest Dis Tuberc 62: 687-695.

14. Cha JK, Kwon KH, Byun SJ, Ryoo SR, Lee JH, et al. (2018) Clinical value of procalcitonin for suspected nosocomial blood stream infection Korean. $J$ Intern Med 33: 176-184. [Crossref]

15. Ericksen RT, Guthrie C, Carroll T (2018) The Use of Procalcitonin for prediction of Pulmonary Bacterial Coinfection in Children with Respiratory Failure Associated with Viral Bronchiolitis. Clinical Pediatrics 14:9922818816432. [Crossref]

16. Joseph P, Godofsky E (2018) Outpatient Antibiotic Stewardship: A Growing Frontier-Combining Myxovirus Resistance Protein A with Other Biomarkers to Improve Antibiotic Use. Open Forum Infect Dis 5: ofy024. [Crossref]

17. Toikka P, Irjala K, Juven T, Virkki R, Mertsola J, et al. (2000) Serum procalcitonin, C-reactive protein and interleukin-6 for distinguishing bacterial and viral pneumonia in children. Pediatr Infect Dis J 19: 598-602. [Crossref]
18. Zhu G, Zhu J, Song L, Cai W, Wang J (2015) Combined use of biomarkers for distinguishing between bacterial and viral etiologies in pediatric lower respiratory tract infections. Infect Dis 47: 289-93. [Crossref]

19. 19. Branche AR, Walsh EE, Vargas R, Hulbert B, Formica MA, et al. (2015) Serum Procalcitonin measurement and viral testing to guide antibiotic use for respiratory infections in hospitalized adults. A randomized controlled trial. J Infect Dis 212: 1692-700. [Crossref]

20. Gilbert DN (2010) Use of plasma procalcitonin levels as an adjunct to clinical microbiology. J Clin Microbiol 48: 2325-2329. [Crossref]

21. Linscheid P, Seboeck D, Nylen ES, Langer I, Schlatter M, et al. (2003) In vitro and in vivo calcitonin I gene expression in parenchymal cells: a novel product of human adipose tissue. Endocrinology 144: 5578-5584. [Crossref]

22. Melendi GA, Laham FR, Monsalvo C, Casellas JM, Israele V, et al. (2007) Cytokine profiles in the respiratory tract during primary infection with human metapneumovirus, respiratory syncytial virus or influenza virus in infants. Pediatrics 120: e410-e415. [Crossref]

23. Hedlund J, Hansson LO (2000) Procalcitonin and C reactive protein levels in community-acquire pneumonia: correlation with etiology and prognosis. Infection 28 : 68-73. [Crossref]

24. Hausfater P, Garric S, Ben Ayed S, Rosenhein M, Bernard M, et al. (2002) Usefulness of procalcitonin as a marker of systemic infection in emergency department patients: a prospective study. Clin Infect Dis 34: 895-901.

25. Kocazeybek B, Kucukoglu S, Oner YA (2003) Procalcitonin and C-reactive protein in infective endocarditis: correlation with etiology and prognosis. Chemotherapy 49: $76-84$

Copyright: $\odot 2019$ El Ftouh S. This is an open-access article distributed under the terms of the Creative Commons Attribution License, which permits unrestricted use, distribution, and reproduction in any medium, provided the original author and source are credited. 